\title{
Transient Gyral Enhancement After Epileptic Seizure in a Patient with CREST Syndrome
}

\author{
CREST Sendromlu Bir Olguda Epileptik Nöbet Sonrası Gelişen \\ Geçici Giral Kontrastlanma
}

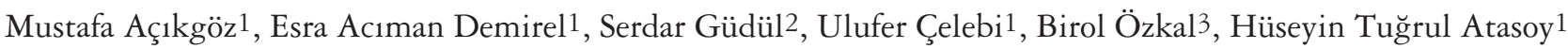 \\ 1Bulent Ecevit University Faculty of Medicine, Department of Neurology, Zonguldak, Turkey \\ 2Karadeniz Eregli State Hospital, Clinic of Neurology, Zonguldak, Turkey \\ ${ }^{3}$ Alanya State Hospital, Clinic of Neurosurgery, Antalya, Turkey
}

\begin{abstract}
Limited scleroderma, also termed CREST syndrome (calcinosis cutis, Raynaud's phenomenon, esophageal dysmotility, sclerodactyly and telangiectasia), is a form of scleroderma which is an autoimmune connective tissue disease. Neurological involvement is less common than other system involvements in scleroderma. Epileptic seizure is a rare neurological complication. Gyral enhancement is not an expected finding during disease. Gyral enhancement is contrast enhancement of superficial brain parenchyma and it usually occurs as a result of vascular, inflammatory, infectious and neoplastic processes. A-sixty-seven-year old female patient, who was diagnosed as CREST syndrome for three years was admitted to our hospital. She had an epileptic seizure three days ago and behavioral changes after the seizure. There was not epilepsy diagnosis in her medical history. In neurological examination; she was apathic and deep tendon reflexes were hyperactive, Hoffman's and Babinski reflexes were positive on the right side of her body. In laboratory studies; anti-nuclear antibody was positive at 1/1000 and anti-centromere antibody was positive. On contrast-enhanced cranial magnetic resonance imaging (MRI); gyral enhancement was observed in the left parieto-occipital region. Cerebrospinal fluid tests were within normal limits. Electroencephalography demonstrated diffuse cerebral dysfunction. We administrated antiepileptic drug to the patient during hospitalization. On the follow up, apathy and restriction of the cooperation were improved. Epileptic seizure did not recur. After ten days, in the control cranial MRI, gyral enhancement was reduced significantly. Neurological involvement in CREST syndrome is rare and epileptic seizures have been appeared in a limited number in the literature. Inflammatory and vascular processes can cause gyral enhancement, but also it must be kept in mind that gyral enhancement can be observed transiently after epileptic seizure.
\end{abstract}

Keywords: CREST syndrome, epileptic seizure, gyral enhancement

$\ddot{O} z$

Sınırlı skleroderma; otoimmün bağ dokusu hastalığıı olan sklerodermanın bir formudur ve CREST sendromu (kalsinozis kutis, Raynaud fenomeni, özefageal dismotilite, sklerodaktili ve telenjiektazi) olarak da adlandırılır. Sklerodermada nörolojik tutulum diğer sistem tutulumlarına göre daha az görülür. Epileptik nöbet ise nadir görülen nörolojik komplikasyonlardandır. Hastalıkta giral kontrastlanma beklenen bir bulgu değildir. Giral kontrastlanma, beyin parankiminin yüzeyel kontrast tutulumudur ve genellikle vasküler, enflamatuvar, enfeksiyöz ve neoplastik süreçler sonucu ortaya çıkar. Üç yıldır CREST sendromu tanısı olan 67 yaşında kadın hasta hastanemize başvurdu. Üç gün önce epileptik nöbet geçirmişti ve nöbet sonrasında davranış değişiklikleri mevcuttu. Özgeçmişinde epileptik nöbet hikayesi yoktu. Nörolojik muayenesinde; apatikti ve kooperasyonu kısıtlı idi. Derin tendon refleksleri yaygın olarak artmıştı, sağda Hoffman ve Babinski refleksleri pozitifti. Laboratuvar incelemelerinde anti-nükleer antikor pozitifti (1/1000) ve anti-sentromer antikor pozitifti. Kontrastli kraniyal manyetik rezonans görüntülemede (MRG) sol paryeto-oksipital bölgede giral kontrast tutulumu izlendi. Beyin omurilik sıvısı tetkikleri normal sınırlarda idi. Çekilen elektroensefalografide; diffüz serebral disfonksiyon gözlendi. Yatışında hastaya antiepileptik tedavi başlandı. Takipte hastanın apatisi ve kooperasyon

Address for Correspondence/Yazışma Adresi: Mustafa Açıkgöz MD, Bulent Ecevit University Faculty of Medicine, Department of Neurology, Zonguldak, Turkey Phone: +905332413889 E-mail: mustafaacikgoz01@gmail.com ORCID ID: orcid.org/0000-0002-0645-5765

Received/Geliş Tarihi: 12.02 .2016 Accepted/Kabul Tarihi: 21.08 .2016

${ }^{\circ}$ Copyright 2017 by Turkish Neurological Society

Turkish Journal of Neurology published by Galenos Publishing House. 


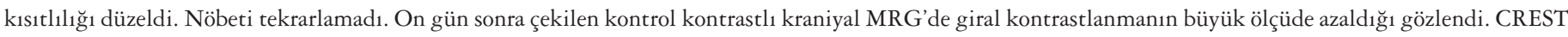

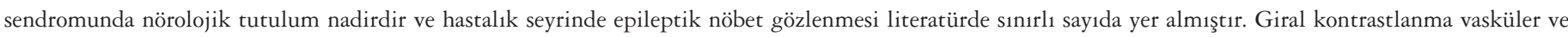
enflamatuvar süreçlere ikincil olarak ortaya çıkabilmektedir fakat epileptik nöbet sonrası geçici olarak gözlenebildiği de akılda tutulmalıdır.

Anahtar Kelimeler: CREST sendromu, epileptik nöbet, giral kontrastlanma

\section{Introduction}

Scleroderma (systemic sclerosis) is a multisystem disorder with unknown etiology characterized by fibrosis of visceral organs, vascular structures, and skin (1). The disease is most commonly seen in the 30-50 years' age range and the female to male ratio is 8:1 (2). Incidence and prevalence may show significant differences in relation to ethnic and regional factors. In studies conducted in different countries, the incidence of scleroderma ranged from 10.9 to 43 per million with a prevalence ranging from 56 to 341 per million (3). No studies have been conducted on this subject in our country.

The pathogenesis of the disease has not yet been fully understood. Extracellular collagen matrix accumulation in tissues, vascular lesions in small arteries, and changes in cellular and humoral immunity such as disease-specific antibody development are thought to be responsible for the pathophysiology (4). Clinical and laboratory studies have revealed that increased vascular permeability secondary to perivascular inflammatory cell infiltration plays an essential role in the pathogenesis of the disease, and that vascular structures are the main target (5). Perivascular infiltration, gliosis, thickening of vessel walls, thrombus and focal parenchymal necrosis were observed in biopsies of nine patients (6). Although all forms of scleroderma are similar in pathophysiology, they show clinical differences in terms of organ involvement.

The disease has two forms, mainly systemic and localized scleroderma. Systemic scleroderma may occur in the form of diffuse or limited scleroderma (CREST syndrome). Diffuse scleroderma affects mainly the skin, gastrointestinal tract, lungs, heart, and kidneys, and causes fibrosis in the connective tissues of organs (7). CREST syndrome is characterized by calcinosis cutis, Raynaud phenomenon, esophageal dysmotility, sclerodactyly, and telangiectasia, and at least three of these 5 symptoms must be present for diagnosis (8). Localized scleroderma is histopathologically similar to systemic scleroderma, but its effects are mostly confined to the skin and subcutaneous tissue (7).

Unlike other collagen tissue diseases, neurologic involvement is rare in scleroderma (1). Studies show that this rate varies between $1 \%$ and $40 \%$. The form with the most common neurologic involvement is localized scleroderma and the most common neurologic symptom is epileptic seizure. The localized scleroderma form, in which facial and scalp tissue are also affected, is called "en coup de sabre", and epileptic seizures are most commonly seen in this form. Peripheral nerve involvement is most frequently observed in patients with diffuse scleroderma and epileptic seizures are less frequent (6). In CREST syndrome, which is a limited form of scleroderma, epileptic seizures are very rare $(1,6)$.

In CREST syndrome, gyral enhancement is not an expected finding. Gyral enhancement is superficial contrast enhancement of the brain parenchyma and usually occurs as a result of vascular or inflammatory processes. Besides neoplastic processes, it has been reported that it can be observed temporarily in epileptic seizures $(9,10)$.

The aim of this article was to discuss the development of epileptic seizures and the accompanying temporary gyral enhancement in a patient with CREST syndrome because there is limited number of cases in the literature.

\section{Case Report}

A 67-year-old female patient, who was diagnosed as having CREST syndrome three years ago and who had no previous epileptic seizure history, was brought to our neurology outpatient clinic due to generalized tonic clonic seizure of 5-minute duration three days previously, and subsequent ongoing behavioral change. From the patient's history, it was learned that she was admitted to hospital with purple discoloration of the skin of the hand three years ago and was diagnosed as having CREST syndrome through the detection of anti-nuclear antibody (ANA) and anti-centromere antibody positivity in addition to cutaneous calcification, Raynaud phenomenon, esophageal dysmotility, and sclerodactyly. Other than that, she had hypothyroidism and diabetes mellitus. She was on $600 \mathrm{mg} /$ day hydroxychloroquine sulfate, $800 \mathrm{mg} /$ day pentoxifylline, $0.1 \mathrm{mg} /$ day levothyroxine sodium, and $2 \mathrm{mg} /$ day glimepiride. In the systemic examination, her body temperature was $36.7{ }^{\circ} \mathrm{C}$, blood pressure was $120 / 70 \mathrm{mmHg}$, and heart rate was $82 / \mathrm{min}$. She was conscious, apathetic, and her co-operation was limited. The examination of the cranial nerves was normal and she had no motor deficit. Deep tendon reflexes were diffusely hyperactive. Hoffman and Babinski reflexes were positive on the right side. Liver, kidney, and thyroid function tests, and complete blood count were within normal limits in the laboratory examinations. There was no electrolyte imbalance. The erythrocyte sedimentation rate was $78 \mathrm{~mm} / \mathrm{h}, \mathrm{C}$-reactive protein was $71 \mathrm{mg} / \mathrm{L}$, vitamin B12 was $251 \mathrm{pg} / \mathrm{mL}$, and folic acid was $8.05 \mathrm{ng} / \mathrm{mL}$. Of the vasculitic markers, ANA was $1 / 1000$ positive (centromere pattern) and anti-centromere antibody was positive. Anti-dsDNA, anti-jo-1, anti-Scl-70, anti-Sm, anti-Sm-RNP, anti-SSA, and anti-SSB were negative. Electroencephalography revealed ground activity with slow waves at the frequency of 5-6 Hertz $(\mathrm{Hz})$ theta and $2.5-3 \mathrm{~Hz}$ delta, and it was moderately compatible with diffuse cerebral dysfunction. There were no parenchymal lesions on contrast-enhanced cranial magnetic resonance imaging (MRI), but a gyral enhancement pattern was observed in the left parietooccipital region. There was no acute diffusion limitation on diffusion MRI (Figure 1). Lumbar puncture values were as follows: cerebrospinal fluid (CSF) opening pressure $11 \mathrm{~cm} \mathrm{H} \mathrm{H}_{2} \mathrm{O}$, glucose: $90 \mathrm{mg} / \mathrm{dL}$ (concurrent blood glucose: $137 \mathrm{mg} / \mathrm{dL}$ ), and protein: $36 \mathrm{mg} / \mathrm{dL}(8-45 \mathrm{mg} / \mathrm{dL})$. There were no cells on microscopic examination, and Gram staining was negative for bacteria. CSF culture, bacterial screening for antibiotic-resistant bacteria, tuberculosis polymerase chain reaction (PCR) and viral PCR 
studies were negative. Transthoracic echocardiography, pulmonary function test, computed tomography examinations of the thorax and abdomen were within normal limits. Antiepileptic treatment (levetiracetam $1000 \mathrm{mg} /$ day) was initiated on admission. From the second day of follow-up, the patient's apathy was observed to improve and the limitation in cooperation was decreased. The seizures did not recur during hospitalization. From the fifth day, the patient's neurologic examination was normal and the control contrast-enhanced cranial MRI taken 10 days after showed a significant decrease in gyral enhancement (Figure 2).

\section{Discussion}

Scleroderma is a rare autoimmune disease characterized by inflammation, vascular injury, and fibrosis in visceral organs, skin, and vascular structures (6). The disease has two forms, mainly systemic and localized scleroderma. While dermal, gastrointestinal, pulmonary, cardiac, and renal involvement are the most common in systemic scleroderma, neurologic involvement is uncommon in contrast to other collagen tissue diseases (1). A total of 6028 patients with scleroderma, $84.5 \%$ females and $15.5 \%$ males, were examined in a review and it was observed that neurologic involvement was most frequently encountered in the localized scleroderma form. Peripheral nerve involvement was rare in patients with localized scleroderma and the most common neurologic event was epileptic seizure (42.5\%). Peripheral nerve involvement was most common in patients with diffuse scleroderma. In 442 cases in which the peripheral nervous system was affected, myopathy $(50.6 \%)$, trigeminal neuropathy $(16.5 \%)$, and peripheral sensorimotor polyneuropathy (14.2\%) were most common. A total of 177 events were detected in the central nervous system involvement. Headache was reported as the most common neurologic symptom with $23.7 \%$. Epileptic seizures were observed in $13.5 \%$ (6). Only three of 24 patients with epileptic seizures had CREST syndrome $(11,12,13)$. Epileptic seizures developed after chronic diarrhea, dehydration and metabolic acidosis in the first case (11), after subarachnoid hemorrhage in the second case (12), and after malignant hypertension and posterior reversible encephalopathy syndrome in the third case (13). In our case, no other cause of epileptic seizure could be found.

Cranial MRIs of 60 patients with systemic scleroderma were examined, and white matter hyperintensities and vasculopathy were observed in $55.8 \%$ and $14.3 \%$, respectively. Gyral enhancement has not been reported (6). In another review of 34 patients with systemic scleroderma, only one of three patients $(8.8 \%)$ with epileptic seizures was reported to have CREST syndrome (1). Cranial MRIs of these 3 patients were also evaluated and reported as normal.

The most specific antibody for diffuse scleroderma is anti-Scl-70 and ANA is positive in almost all patients. In CREST

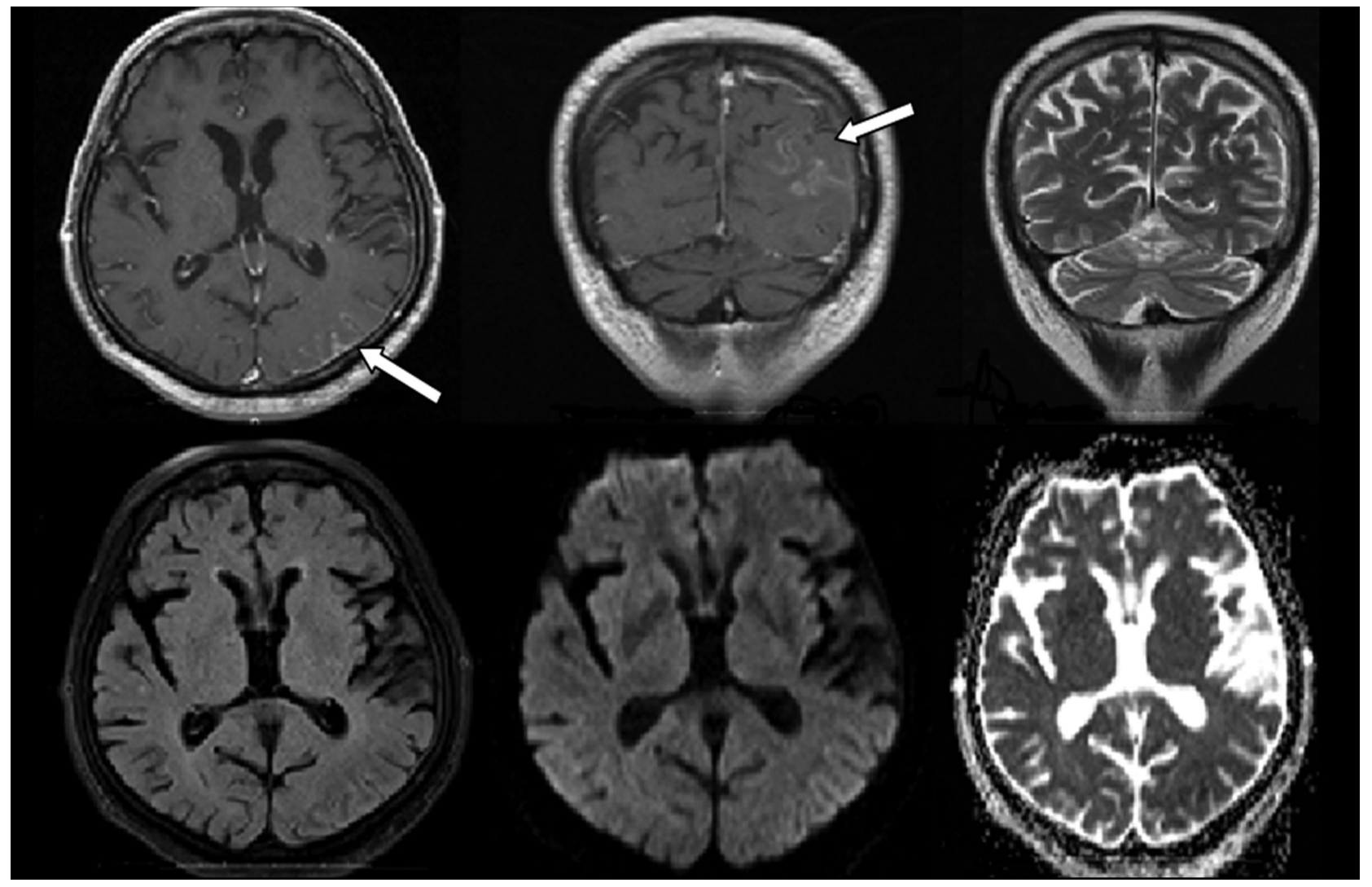

Figure 1. Although contrast enhancement was observed in the left parietooccipital area (arrows) on axial and coronal sections in contrast-enhanced cranial magnetic resonance imaging, no parenchymal lesions were observed on coronal T2 and axial T2-FLAIR weighted sections. There was no evidence of acute ischemia in diffusion-weighted images and apparent diffusion coefficient mapping. 


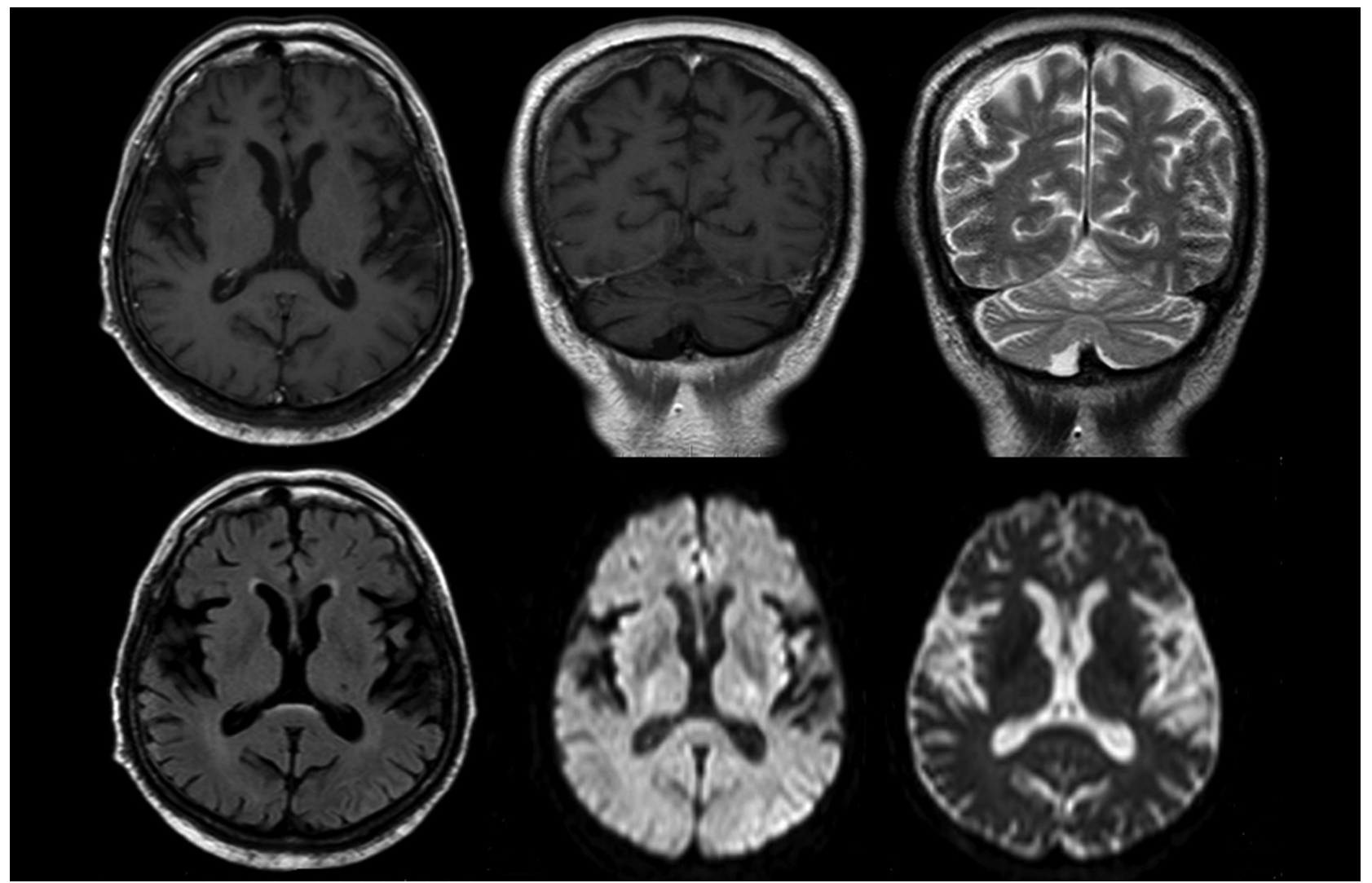

Figure 2. Repeated contrast-enhanced cranial magnetic resonance imaging after 10 days showed a significant decrease in contrast enhancement on axial and coronal sections.

syndrome, the specific antibody is anti-centromere antibody and ANA is highly positive (7). In our case, ANA and anti-centromere antibody were positive, and there were four symptoms required for the diagnosis of CREST syndrome.

Gyral enhancement usually results from deterioration of the blood-brain barrier as a result of vascular and inflammatory processes. Vascular reasons act through vasodilatation most commonly after reperfusion in ischemic brain and in migraine headaches. Inflammatory causes include meningitis and encephalitis (9). Gyral enhancement is not expected in CREST syndrome $(1,6)$. Temporary gyral enhancement after epileptic seizure was first described by Rumack et al. (14) in 1980. Gyral enhancement is thought to result from increased oxygen consumption and resulting hypoxia, hypercarbia, lactic acidosis, and vasodilatation as a result of increased focal metabolism in the epileptogenic area (10). In a retrospective study, 10 patients with epileptic seizures with altered consciousness or neurologic deficits were studied, and half of the patients were observed to have transient gyral enhancement after epileptic seizures (10). In our case, there was also altered consciousness and transient gyral enhancement pattern after epileptic seizure. No evidence of encephalitis or meningitis was found in CSF samples. Other systemic inflammatory diseases were excluded, taking into account the clinical and laboratory characteristics of the patient. The absence of renal, cardiac, and pulmonary involvement, and
ANA and anti-centromere antibody positivity and negative antiScl-70 proved that it was the limited form of scleroderma. After antiepileptic treatment and follow-up, it was observed that the gyral enhancement decreased to a large extent.

In conclusion, CREST syndrome is a form of scleroderma and neurologic involvement is rarely observed. The observation of epileptic seizures in the course of the disease is limited in the literature. Gyral enhancement, although primarily requiring investigation of vascular and inflammatory processes, may also occur due to biochemical changes during epileptic seizures.

Ethics

Informed Consent: Consent forms were completed by all participants.

Peer-review: Externally peer-reviewed.

\section{Authorship Contributions}

Surgical and Medical Practices: M.A., U.Ç., Concept: M.A., E.A.D., Design: M.A., S.G., H.T.A., Data Collection or Processing: M.A., H.T.A., Analysis or Interpretation: M.A., S.G., Literature Search: E.A.D., U.Ç., B.Ö., Writing: M.A., E.A.D., B.Ö.

Conflict of Interest: No conflict of interest was declared by the authors.

Financial Disclosure: The authors declared that this study received no financial support. 


\section{References}

1. Araújo FG, Amaral TN, Appenzeller S, de Carvalho JF. Seizures in systemic sclerosis. Rheumatol Int 2013;33:1721-1724.

2. Mayes MD. Scleroderma epidemiology. Rheum Dis Clin North Am 1996;22:751-764.

3. Barnes J, Mayes MD. Epidemiology of systemic sclerosis: incidence, prevalence, survival, risk factors, malignancy and environmental triggers. Curr Opin Rheumatol 2012;24:165-170.

4. Derk CT, Jimenez SA. Systemic sclerosis: current views of its pathogenesis. Autoimmun Rev 2003;2:181-191.

5. Katsumoto TR, Whitfield ML, Connolly MK. The pathogenesis of systemic sclerosis. Annu Rev Pathol 2011;6:509-537.

6. Amaral TN, Peres FA, Lapa AT, Marques-Neto JF, Appenzeller S. Neurologic involvement in scleroderma: a systematic review. Semin Arthritis Rheum 2013; 43:335-347.

7. Silver RM. Clinical aspects of systemic sclerosis (scleroderma). Ann Rheum Dis 1991;50(Suppl 4):854-861.
8. Akiyama Y, Tanaka M, Takeishi M, Adachi D, Mimori A, Suzuki T. Clinical, serological and genetic study in patients with CREST syndrome. Intern Med 2000;39:451-456.

9. Smirniotopoulos JG, Murphy FM, Rushing EJ, Rees JH, Schroeder JW. Patterns of contrast enhancement in the brain and meninges. Radiographics 2007;27:525-551.

10. Silverstein AM, Alexander JA. Acute postictal cerebral imaging. AJNR Am J Neuroradiol 1998;19:1485-1488.

11. Wasserman JK, Glikstein R, Sharma M. 45-Years Between Skin Lesions and CNS Symptoms in a Patient with Scleroderma. Can J Neurol Sci 2012;39:686-687.

12. Pathak R, Gabor AJ. Scleroderma and central nervous system vasculitis. Stroke 1991;22:410-413.

13. Poon WL, Mok CC. Reversible posterior leucoencephalopathy in scleroderma. Ann Rheum Dis 2005;64:1803-1804.

14. Rumack CM, Guggenheim MA, Fasules JW, Burdick D. Transient positive postictal computed tomographic scan. J Pediatr 1980;97:263-264. 